Article

\title{
Seedling Characteristics of Three Oily Species before and after Root Pruning and Transplant
}

\author{
Ofelia Andrea Valdés-Rodríguez ${ }^{1}$ and Arturo Pérez-Vázquez ${ }^{2, *}$ \\ 1 Academia de Desarrollo Regional Sustentable El Colegio de Veracruz, Xalapa 91000, Mexico \\ 2 LPI3 Colegio de Postgraduados, Predio Tepetates, Veracruz 91690, Mexico \\ * Correspondence: parturo@colpos.mx; Tel.: +52-2292664494
}

Received: 23 May 2019; Accepted: 4 July 2019; Published: 30 July 2019

\begin{abstract}
Moringa oleifera Lam. (Moringa), Jatropha curcas L. (Jatropha), and Ricinus communis L. (Ricinus) are oily species known by their capability to grow in tropical and subtropical lands. However, there are no studies comparing their growth and recovery capabilities after root pruning and transplant. The purpose of this research was to compare and analyze propagation, growth, and recovery performance of these species after root pruning and transplant. We sowed 100 seeds per species and monitored their survival and growth during a 63-day period; after this, we uprooted the plants and pruned their roots $4.0 \mathrm{~cm}$ from their base and transplanted them. We monitored their recovery over 83 days, and then uprooted plants and measured above- and belowground data, digitized their roots in three dimensions, and calculated biomass fractions. With this information, we established allometric equations to estimate biomass fractions and root distribution models. Results indicated that Ricinus had the highest propagation capabilities. Jatropha and Ricinus had similar recovery after root pruning and transplant. Moringa had the lowest propagation and recovery from transplant. Concerning belowground data, root pruning increased root density more than three times in Moringa, four times in Ricinus, and six times in Jatropha. Nevertheless, the three species maintained natural root trays. Ricinus had the longest and thinnest roots and the highest number of branches, followed by Jatropha, and finally Moringa, with the smallest quantity and the shortest and thickest roots. We concluded that the three species recovered well from root pruning and transplant, with improved root structure upon applying these practices.
\end{abstract}

Keywords: Moringa oleifera; Jatropha curcas; Ricinus communis; root systems

\section{Introduction}

Moringa oleifera Lam. (Moringa), Ricinus communis L. (Ricinus), and Jatropha curcas L. (Jatropha) are oily species recognized by their multiple industrial applications [1-3]. In their original region, Moringa trees are typically found growing in areas with poor sandy soils and at altitudes below $1400 \mathrm{~m}$ above sea level (masl), where it can survive temperatures up to $40{ }^{\circ} \mathrm{C}$ and minimal annual rainfalls of $250 \mathrm{~mm}[1,4]$. Ricinus is found in tropical and subtropical lands, where precipitations can be as low as $400 \mathrm{~mm}$ per year and with altitudes going from zero up to 2300 masl [5]. Jatropha is considered to be native to America, where it is found in tropical and subtropical climates with precipitation ranges of $800-3000 \mathrm{~mm} /$ year, diverse soil types, temperature ranges of $10.5-32{ }^{\circ} \mathrm{C}$, and altitudes up to 1000 masl [6,7]. However, there is no information comparing their capability to survive and develop under the same environmental conditions and under stressful situations, such as transplant shocks. This data is important if these species are to be sown intercropped or when one of them, among the others, is recommended as an alternative new crop. Another aspect to consider is that for their establishment, direct sowing requires higher investment in land preparation and to take care of the seedlings at the field. Therefore, the most common practice consists of propagating 
seedlings under greenhouse conditions and then transplanting them to the field. This method regularly requires roots to be extracted out of their container, where a fraction of the roots are cut to avoid bending [8]. Although there are not specific recommendations for how to trim the roots of these species, it is known that this practice induces a "transplant shock", which is a condition of distress caused by root injuries and the need for the plant to adapt to a new environment [9]. Besides this, it has been reported that root pruning can decrease vegetative growth rates in trees and crops of different species but, at the same time, it can stimulate the development of new roots, contributing to the improvement of root biomass [10,11].

Root biomass and root morphology determine the capacity of the plant to capture nutrients and water, affecting its survival and development. Roots also provide support to plants; consequently, a strong root system with a good morphology will facilitate plant anchorage against uprooting forces, like strong winds or storms [12]. Therefore, learning about stem and root development after trimming and transplant is an important knowledge for determining the key factors for successful establishment on the field [13], and to make decisions over which crop is more appropriate for specific situations. Hence, studying propagation, growth patterns, and responses to root pruning and transplant of Jatropha, Moringa, and Ricinus, will allow us to understand their natural capabilities and their particular strategies to recover from transplant shock.

We also have to consider that root trimming can change the original root structure of the plant; therefore, relationships between above- and belowground data will be affected. Even though there are studies involving above- and belowground parameters of these three species [14-17], none of them evaluates plant characteristics and their performance before and after trimming of roots and transplant.

Previous research from these species indicates that during its juvenile stage, Moringa develops a napiform tap root from which very thin second-order roots emerge [18], Jatropha develops a thick tap root with mainly four thick laterals and few second-order roots [16], and Ricinus develops a tap root with many thin laterals and second-order roots [19]. The main function of the tap root is to provide anchorage, while laterals and second-order roots increase stabilization and the search for resources [20]. Thus, if we prune the main roots, plants would have to adapt their structure to preserve their original functions. We theorized that the tap root may develop new vertically oriented roots to provide anchorage, while new second-order roots will emerge from the trimmed laterals to maintain stability and search for more resources. Yet, plant responses will depend on the specific strategy of each species to survive and recover from transplant shock. However, there are no data of pruned root development for any of these plants, nor there are models linking above- and belowground biomass fractions after root pruning and transplant. Thus, we want to determine how root trimming affects plant morphology and the key differences of each species representing above- and belowground relations prior to and post-transplant, in order to understand how each one deals with the shock. Our specific questions were: Which is the species with the highest propagation capabilities? How does each species respond to root trimming and transplant? Which one has the fastest recovery process? Does root pruning affect the natural below- and aboveground structures?

Therefore, the aims of this research were 1) to evaluate propagation and growth characteristics of Moringa, Ricinus, and Jatropha in a subtropical climate, 2) compare their above- and belowground relationships before and after root pruning, and 3) analyze their root structure by modeling root biomass distribution and above- and belowground relationships after pruning to compare the plant capabilities of each species.

\section{Materials and Methods}

\subsection{Plant Material}

All plant material was obtained from Mexican collections. Ricinus seeds were collected at the Mexican plateau in the state of San Luis Potosi $\left(22.191744^{\circ} \mathrm{N},-101.010241^{\circ} \mathrm{W}\right.$; semi-dry semi-warm climate—Bsh) during June; average seed weight ( \pm standard deviation) was $487 \pm 52 \mathrm{mg}$. 
Moringa seeds came from the state of Morelos $\left(18.523889^{\circ} \mathrm{N},-98.790278^{\circ} \mathrm{W}\right.$; sub-humid warm climate- $\left.-\mathrm{Aw}_{1}\right)$, where they were collected during August; average seed weight ( \pm standard deviation) was $310 \pm 74 \mathrm{mg}$. Jatropha seeds were collected in Alvarado, Veracruz $\left(18.79386^{\circ} \mathrm{N},-95.79886^{\circ} \mathrm{W}\right.$; humid-warm climate- $-\mathrm{Aw}_{2}$ ) during September; average seed weight ( \pm standard deviation) was $686 \pm$ $89 \mathrm{mg}$. All seeds were stored in a refrigerator at $-5{ }^{\circ} \mathrm{C}$ prior to their use on the first day of October. For each species, 100 seeds were selected. We selected seeds after considering if they were free from damage or scratches.

\subsection{Environmental Conditions and Substratum}

The experiment was established at the facilities of Colegio de Postgraduados, Campus Veracruz, which is located in the municipality of Manlio Fabio Altamirano, Veracruz $\left(19^{\circ} 16^{\prime} 00^{\prime \prime} \mathrm{N}, 96^{\circ} 16^{\prime} 32^{\prime \prime}\right.$ $\mathrm{W}, 18 \mathrm{masl})$. The climate at the site is considered sub-humid warm $\left(\mathrm{Aw}_{1}\right)$. The experimental site was located under a square sun mesh providing $50 \%$ shading. The sun mesh was supported by poles and open by the four sides. During the experiment, environmental temperature and humidity of the site were registered by the local climatic station. The substrate used for this experiment consisted in a homogeneous mix of 5:1 sand (collected from a natural dune) and compost made of sugarcane bagasse and soil of the region (sand/compost 5:1). Physical and chemical analysis of separate samples of sand and compost were previously performed by the soil laboratory of Colegio de Postgraduados. The granulometric characterization (Bouyoucos method) for sand indicated 96\% sand, $2.5 \%$ silk, and $1.5 \%$ clay; compost consisted of $52 \%$ sand, $28 \%$ silk, and $20 \%$ clay; $\mathrm{pH}$ (electronic potentiometer) of 7.03 for sand and 7.01 for compost; nitrogen (N) (Kjeldahl method) not detected for sand and $1.05 \%$ for compost.

\subsection{Germination and Survival}

This experiment consisted of a random design with 100 seeds per species. Each seed was placed inside a plastic bag of $20 \mathrm{~cm}$ length and $15 \mathrm{~cm}$ wide. The bag was filled with sand/compost 5:1 substratum. Bags were labeled for identification and randomly distributed over three tables ( $1.2 \mathrm{~m}$ height). Seeds and seedlings were watered every morning until excess water drained away during a 63-day period.

The number of germinated and survival plants were registered daily. The percentage of germination was estimated on day 63 as the number of germinated seedlings over the number of sowed seeds. The mean germination time in days was calculated as the time when $50 \%$ of seeds have germinated.

\subsection{Aboveground Growth before Transplant}

The experiment consisted of a random design with 100 seedlings per species. Seeds that did not germinate from the previous experiment were replaced with germinated seeds from storage. For each seedling, we established an independent register to maintain its age corresponding to a fixed period of measurement, which was set every seven days. We measured plant height (as the length from the base of the stem to the highest leaf tip), root collar diameter (RCD) (using a digital caliper with $0.01 \mathrm{~mm}$ precision), leaf length and width of the youngest fully mature leaf (using a tape measure with $1.0 \mathrm{~mm}$ precision), and we counted the number of leaves. The leaf area of the youngest fully mature leaf was estimated for Jatropha as in Liv et al. [21], for Ricinus as in Jain and Misra [22], and for Moringa, the compound leaf area was estimated as in Valdés-Rodriguez [14]. Each plant was measured until the 63rd day after sprouting.

\subsection{Leaf Thickness and Weight Measurements}

Six healthy leaves of each species were randomly selected and measured by their blade length, width (using a tape measure, $1 \mathrm{~mm}$ precision), and thickness, without veins and including veins (using a digital caliper, $0.01 \mathrm{~mm}$ precision); petiole length, thickness at the base of the bud, and thickness at the base of the blade. Following this, leaves were divided in blade and petiole and weighed 
(using an analytical balance with $0.0001 \mathrm{~g}$ precision). For Moringa, only one leaflet of the compound leaf was selected.

\subsection{First Uprooting and Belowground Measurements}

Plants were uprooted when they were 63 days old. Root systems were measured as follows: length of tap and lateral roots using a tape measurement with $1 \mathrm{~mm}$ precision; diameter of tap and lateral roots at the base and at the tip of the roots using a digital caliper with $0.01 \mathrm{~mm}$ precision, and number of lateral roots. We labeled tap root as the one emerging from the center of the stump of the plant, and lateral roots as the ones emerging from the main trunk. For each root system, we estimated the volume of tap and lateral roots as in Valdés et al. [16].

\subsection{Root Pruning and Transplant}

The roots of the uprooted plants were gently cleaned to remove excess of soil in order to observe the bare roots, and all roots were cut at a distance of $4.0 \mathrm{~cm}$ from the base. We then transplanted each plant in a plastic bag of $50 \mathrm{~cm}$ length and $30 \mathrm{~cm}$ width filled with the substratum (sand/compost 5:1) and watered each bag until field capacity. After this procedure, we watered the plants every two days during a period of 83 days.

\subsection{Aboveground Measurements after Transplanting}

We waited for a period of 30 days post-transplant before measuring plant height, root collar diameter, leaf area, and the number of leaves, branches, flowers, and fruits in individuals that presented these parts. Measurements were then taken about every two weeks for a period of 53 days.

\subsection{Second Uprooting and Belowground Measurements}

At 83 days post-transplanting, 20 plants per species were randomly selected and uprooted again, and their root systems were measured as in the first uprooting. Additionally, the root structure of one plant from each species was digitized as in Valdes et al. [10]. Digitized roots were projected in a three-dimensional scheme by using the program Visualea [23] to obtain a graphical representation of the effects that trimming of roots had had over root systems.

\subsubsection{Root Distribution Models}

For each species, roots thicker than $3.0 \mathrm{~mm}$ were counted and measured by length, thickness, and angle of inclination along horizontal and vertical axes every $50 \mathrm{~mm}$, with the help of macros implemented in Excel 2010 ${ }^{\circledR}[14,16]$. After this, based on the projected roots, we tested logistic and sigmoid models available at the fit regression tool of SigmaPlot 10.0 to obtain representative models of root volume distribution. The model with the highest coefficient of determination $\left(\mathrm{r}^{2}\right)$ for each species was selected to represent and compare root volume distribution among species.

\subsubsection{Biomass Estimation by Allometric Relationships}

Biomass estimation was determined by considering the highest correlation between the allometric data (plant height, RCD, number of leaves, and leaf area) and leaf, stem, and root biomass. After this, we tested linear, logarithmic, and power regression models for biomass estimation [24-26]. The best model was selected considering the highest $\mathrm{r}^{2}$ of each estimated variable.

\subsection{Statistical Analysis}

Comparisons of germination and survival among species were performed by a log-rank test and the Kaplan-Meier method with a significance level of 0.01 and using SigmaPlot 10.0 software. Since we only tested 100 seeds per species, these germination results were compared with previous 
experiments reported for the same genotypes of these species at the same site. This way, we presented a discussion over propagation capacities of each species at this site.

For the first growing phase (previous to the first uprooting), we compared aboveground parameters per each sampling period, while for the second growing phase (post-transplant), we compared only the last measurement (83 days post transplanting). Since all the plants were pruned and transplanted, post-transplant data were compared with plants of the same genotype that had been grown without transplanting during previous experiments at the same site.

Above- and belowground relationships were evaluated by the Pearson product moment correlation, and relationships between each two pair of variables were evaluated at 0.05 and 0.01 significance levels.

Comparisons between species were conducted by one-way analysis of variance (ANOVA). For each group of data, normality and equal variance tests were performed before ANOVA; therefore, if any of these tests failed, the non-parametric Kruskal-Wallis method was used, otherwise the parametric ANOVA was used. Post hoc tests of paired samples were accomplished by the Tukey method when samples passed normality and equal variance tests; otherwise the non-parametric Dunn's method was used. All comparisons were performed at a 0.05 significance level. SigmaPlot 10.0 software was used for all analyses.

\section{Results}

\subsection{Germination and Survival}

Germination curves were different among species $(\mathrm{P}<0.001)$, Ricinus had the fastest germination time and the highest germination percentage, followed by Jatropha and Moringa. These results, and data from previous experiments performed in this site with the same genotypes, are presented in Table 1.

Table 1. Percentage and average germination days of Moringa oleifera, Jatropha curcas, and Ricinus communis obtained in this and previous experiments at the experimental site.

\begin{tabular}{|c|c|c|c|c|c|c|c|c|c|}
\hline \multirow{2}{*}{$\begin{array}{c}\text { Species } \\
\text { Variable }\end{array}$} & \multicolumn{3}{|c|}{ Moringa } & \multicolumn{3}{|c|}{ Ricinus } & \multicolumn{3}{|c|}{ Jatropha } \\
\hline & Exp1 & Exp2 & This experiment & Exp1 & Exp2 & This experiment & Exp3 & Exp3 & This experiment \\
\hline Germination percentage & 95.0 & 60.0 & 86.0 & 96.0 & 80.0 & 100.0 & 77.0 & 25.0 & 97.0 \\
\hline Mean germination time (days) & 5.9 & 13.0 & 14.1 & 4.7 & 10.0 & 7.5 & 6.2 & 10.8 & 9.1 \\
\hline Substratum & Sand & Clay & S-C $(5: 1)^{\dagger}$ & Sand & Clay & S-C $(5: 1)^{\dagger}$ & Sand & Clay & S-C $(5: 1)^{\dagger}$ \\
\hline Average Temperature ${ }^{\circ} \mathrm{C}$ ) & 27.0 & 25.5 & 23.2 & 28.7 & 25.5 & 22.2 & 27.4 & 27.4 & 23.2 \\
\hline Humidity (\%) & 88.7 & 78.7 & 73.9 & 88.5 & 78.7 & 71.3 & 73.8 & 73.8 & 73.3 \\
\hline
\end{tabular}

Exp1 [27]; Exp2: [28]; Exp3: [29]. This experiment: ${ }^{+}$Sand/Compost 5:1.

\subsection{First Phase of Seedling Growth}

\subsubsection{Aboveground Measurements}

Statistical analysis indicated that Ricinus was taller than Moringa and Jatropha since day 14 ( $\mathrm{P}<0.001)$, while Jatropha was taller than Moringa until day 35 after sprouting $(\mathrm{P}<0.001)$. By day 42 Moringa and Jatropha registered similar heights $(\mathrm{P}=0.11)$; however, by day 63 , Moringa was taller than Jatropha (Figure 2). Jatropha had the highest root collar diameter since day seven after sprouting $(\mathrm{P}<0.001)$. Jatropha always had the lowest relationship between height and RCD (slender index); while Ricinus had the highest slender index since day 49 after sprouting until the end of the experimental period. Plant growth rates and a comparison with previous data from the same experimental site are shown in Table 2. 
Table 2. Mean growth rates (mm/day) and leaf production (leaf/day) $\pm \mathrm{SE}$ of Moringa oleifera, Jatropha curcas, and Ricinus communis, and environmental conditions registered in this and previous experiments conducted at the experimental site.

\begin{tabular}{ccccccc}
\hline \multirow{2}{*}{ Variable } & \multicolumn{2}{c}{ Moringa } & \multicolumn{2}{c}{ Ricinus } & \multicolumn{2}{c}{ Jatropha } \\
\cline { 2 - 7 } & Exp2 & This experiment & Exp2 & This experiment & Exp1 & This experiment \\
\hline Plant age (days) & 45 & 63 & 45 & 63 & 45 & 63 \\
Height & $4.66 \pm 0.09$ & $3.30 \pm 0.07$ & $5.08 \pm 0.09$ & $5.49 \pm 0.12$ & $4.22 \pm 0.12$ & $2.93 \pm 0.05$ \\
Root collar diameter & $0.09 \pm 0.00$ & $0.10 \pm 0.00$ & $0.14 \pm 0.00$ & $0.14 \pm 0.00$ & $0.19 \pm 0.02$ & $0.23 \pm 0.00$ \\
Leaf production & $0.11 \pm 0.00$ & $0.16 \pm 0.00$ & $0.07 \pm 0.00$ & $0.07 \pm 0.00$ & $0.06 \pm 0.00$ & $0.11 \pm 0.01$ \\
Substratum & Sand & S-C $(5: 1)^{\dagger}$ & Sand & S-C $(5: 1)$ & Sand & S-C (5:1) \\
Temperature $\left({ }^{\circ} \mathrm{C}\right)$ & $26.01 \pm 1.17$ & $24.69 \pm 2.27$ & $26.01 \pm 1.17$ & $24.69 \pm 2.27$ & $24.69 \pm 1.45$ & $24.69 \pm 2.27$ \\
Humidity $(\%)$ & $88.54 \pm 3.03$ & $75.00 \pm 5.90$ & $88.54 \pm 3.03$ & $75.00 \pm 5.90$ & $75.00 \pm 6.61$ & $75.00 \pm 5.90$ \\
\hline
\end{tabular}

Exp1 [16], Exp2 [14], ${ }^{\dagger}$ Sand/Compost 5:1.

\subsubsection{Leaf Measurements}

Moringa had the highest number of leaves since day 35 ( $\mathrm{P}<0.001)$, while Ricinus had the lowest number of leaves since day 49 after sprouting. Leaf area was different among species $(\mathrm{P}<0.001)$ and Ricinus had the highest leaf area. Jatropha registered the thicker blades of the three species $(\mathrm{P}<0.05)$, with $0.26 \mathrm{~mm}$, followed by Ricinus with $0.24 \mathrm{~mm}$, while Moringa had the thinnest blades at $0.23 \mathrm{~mm}$. Ricinus had the heaviest blades (4.1 g), followed by Jatropha (3.2 g), and Moringa had the lightest (0.03 g).

\subsection{Relationships between Above- and Belowground in 63-Day-Old Seedlings}

Root size and morphology were statistically different among species (Table 3, Figure 1). Ricinus had the longest and thinnest roots, while Moringa had the thickest tap root and the lowest number of lateral roots.

Allometric relationships between above- and belowground data indicated that Jatropha had the longest roots in relation with the length of its stem and the highest correlation between RCD and root volume. Moringa had the shortest roots in relation to its height and the highest correlation between height and root volume, while Ricinus had the highest correlation between root volume and leaf area (Table 4).

Table 3. Average root dimensions \pm SE of 63-day-old Moringa oleifera, Jatropha curcas, and Ricinus communis.

\begin{tabular}{cccc}
\hline Parameter $(\mathbf{n}=\mathbf{1 0 0})$ & Moringa & Ricinus & Jatropha \\
\hline Tap root length $(\mathrm{mm})$ & $173.59 \pm 4.20 \mathbf{c}$ & $411.14 \pm 5.92 \mathbf{a}$ & $280.40 \pm 6.14 \mathbf{b}$ \\
Main lateral roots length $(\mathrm{mm})$ & $196.25 \pm 4.79 \mathbf{c}$ & $351.60 \pm 4.17 \mathbf{a}$ & $289.00 \pm 5.24 \mathbf{b}$ \\
Maximum tap root diameter $(\mathrm{mm})$ & $18.5 \pm 0.35 \mathbf{a}$ & $6.09 \pm 0.12 \mathbf{c}$ & $9.71 \pm 0.29 \mathbf{b}$ \\
Main lateral roots diameter $(\mathrm{mm})$ & $1.85 \pm 0.13 \mathbf{b}$ & $1.05 \pm 0.02 \mathbf{c}$ & $3.97 \pm 0.17 \mathbf{a}$ \\
Number of lateral roots & $1.09 \pm 0.03 \mathbf{c}$ & $25.18 \pm 0.48 \mathbf{a}$ & $5.15 \pm 0.28 \mathbf{b}$ \\
Tap root + lateral roots volume $\left(\mathrm{cm}^{3}\right)$ & $23.82 \pm 1.69 \mathbf{a}$ & $11.11 \pm 0.29 \mathbf{b}$ & $23.33 \pm 1.52 \mathbf{a}$ \\
Tap root diameter/Main lateral roots diameter & $12.53 \pm 0.54 \mathbf{a}$ & $5.90 \pm 0.13 \mathbf{b}$ & $2.5 \pm 0.10 \mathbf{c}$ \\
Tap root volume/laterals root volume & $19.88 \pm 1.14 \mathbf{a}$ & $1.29 \pm 0.07 \mathbf{b}$ & $1.40 \pm 0.14 \mathbf{b}$ \\
\hline
\end{tabular}

Different letters in the same row indicate statistical differences $(\mathrm{P}<0.05)$. 
Table 4. Linear correlations between above- and belowground data of Moringa oleifera, Jatropha curcas and Ricinus communis seedlings 63 days after germination.

\begin{tabular}{|c|c|c|c|c|c|}
\hline $\begin{array}{l}\text { Species } \\
(n=100)\end{array}$ & Parameter & Height & RCD & Number of Leaves & $\begin{array}{c}\text { Leaf Area of the Youngest } \\
\text { Fully Mature Leaf }\end{array}$ \\
\hline \multirow{6}{*}{ Jatropha } & Tap root length & $0.48^{* *}$ & $0.51^{* *}$ & 0.34 * & 0.22 \\
\hline & Laterals length & $0.49 * *$ & $0.52 * *$ & 0.24 & 0.23 \\
\hline & $\begin{array}{l}\text { Tap root } \\
\text { diameter }\end{array}$ & $0.44^{* *}$ & $0.54^{* *}$ & 0.10 & 0.26 \\
\hline & $\begin{array}{l}\text { Lateral roots } \\
\text { diameter }\end{array}$ & $0.40^{* *}$ & $0.57^{* *}$ & 0.18 & 0.12 \\
\hline & $\begin{array}{c}\text { Number of } \\
\text { Laterals }\end{array}$ & 0.16 & 0.15 & -0.11 & -0.03 \\
\hline & Root volume & $0.62 * *$ & $0.64^{* *}$ & 0.17 & 0.21 \\
\hline \multirow{6}{*}{ Moringa } & Tap root length & 0.18 & 0.01 & -0.06 & 0.16 \\
\hline & $\begin{array}{l}\text { Lateral roots } \\
\text { length }\end{array}$ & $0.31^{* *}$ & 0.09 & -0.11 & $0.31^{* *}$ \\
\hline & $\begin{array}{l}\text { Tap root } \\
\text { diameter }\end{array}$ & $0.29 * *$ & $0.44^{* *}$ & 0.02 & 0.14 \\
\hline & $\begin{array}{l}\text { Lateral roots } \\
\text { diameter }\end{array}$ & $0.33^{* *}$ & $0.40^{* *}$ & 0.03 & $0.35^{* *}$ \\
\hline & $\begin{array}{l}\text { Number of } \\
\text { lateral roots }\end{array}$ & 0.10 & 0.07 & -0.06 & 0.13 \\
\hline & Root volume & $0.66^{* *}$ & $0.43^{* *}$ & -0.06 & $0.59 * *$ \\
\hline \multirow{6}{*}{ Ricinus } & Tap root length & 0.30 * & $0.40^{* *}$ & 0.06 & 0.08 \\
\hline & $\begin{array}{l}\text { Lateral roots } \\
\text { length }\end{array}$ & $0.23 *$ & $0.39^{* *}$ & 0.16 & 0.11 \\
\hline & $\begin{array}{l}\text { Tap root } \\
\text { diameter }\end{array}$ & $0.29 * *$ & $0.42 * *$ & -0.07 & 0.05 \\
\hline & $\begin{array}{l}\text { Lateral roots } \\
\text { diameter }\end{array}$ & -0.09 & -0.11 & -0.17 & $0.20^{*}$ \\
\hline & $\begin{array}{l}\text { Number of } \\
\text { lateral roots }\end{array}$ & $0.26^{* *}$ & 0.08 & 0.07 & -0.16 \\
\hline & Root volume & $0.37^{* *}$ & $0.40^{* *}$ & -0.07 & $0.70 * *$ \\
\hline
\end{tabular}

* Significant at $0.05 ; *$ significant at $0.01 ; \mathrm{RCD}=$ root collar diameter.

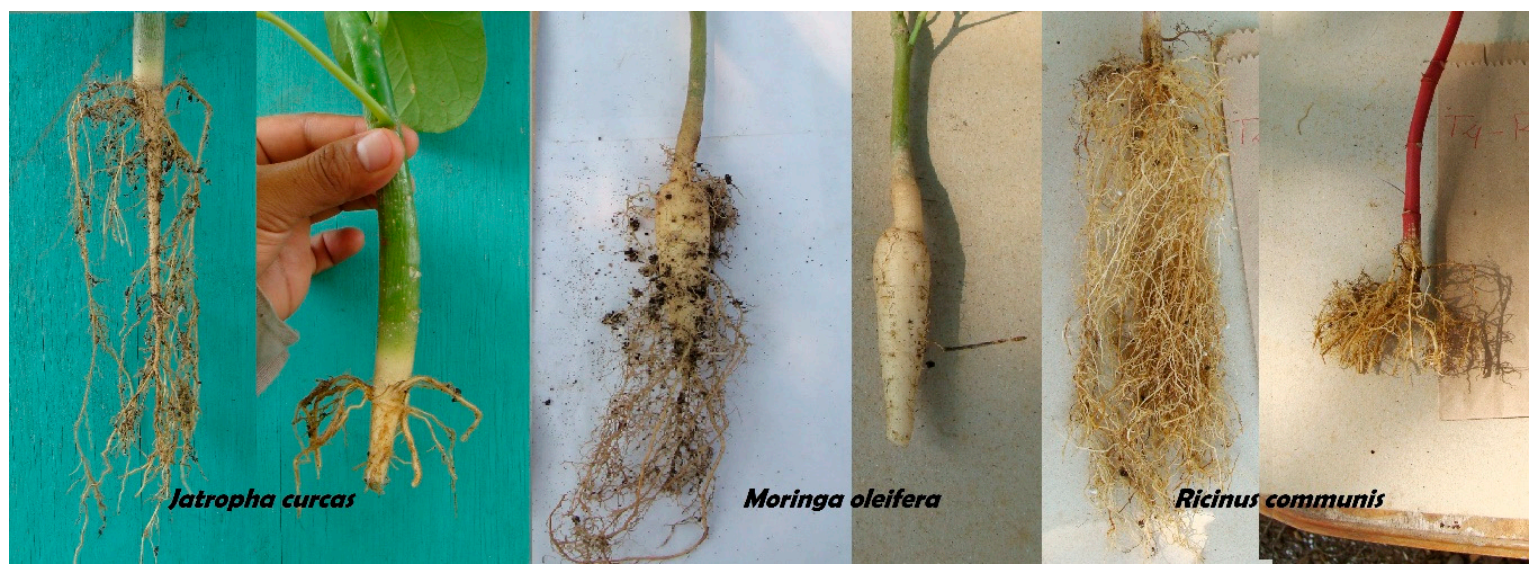

Figure 1. Roots of 63-day-old Jatropha curcas, Moringa oleifera, and Ricinus communis before and after pruning. 


\subsection{Second Phase: Plant Performance after Transplanting}

\subsubsection{Aboveground Measurements}

The three species registered a 100\% survival rate after transplanting. Nevertheless, transplant caused the loss of $18 \%$ of the leaves of Moringa and $5.0 \%$ of Ricinus, but defoliation was not observed for Jatropha. At the end of the experimental period, we recorded the highest leaf area of the first mature leaf in Ricinus, being 1.5 times bigger than Jatropha and 2.0 times bigger than Moringa.

The highest stem lengths were registered in Ricinus, and the thickest stems were recorded in Jatropha (Figure 2). Ricinus was the only species to reach maturity, with $12 \%$ of its plants flowering 46 days after transplant and 45\% of individuals flowering and fruiting 142 days after sprouting. In order to compare results, data from non-transplanted plants registered from previous experiments at the same site are shown in Table 5.

a) Stem

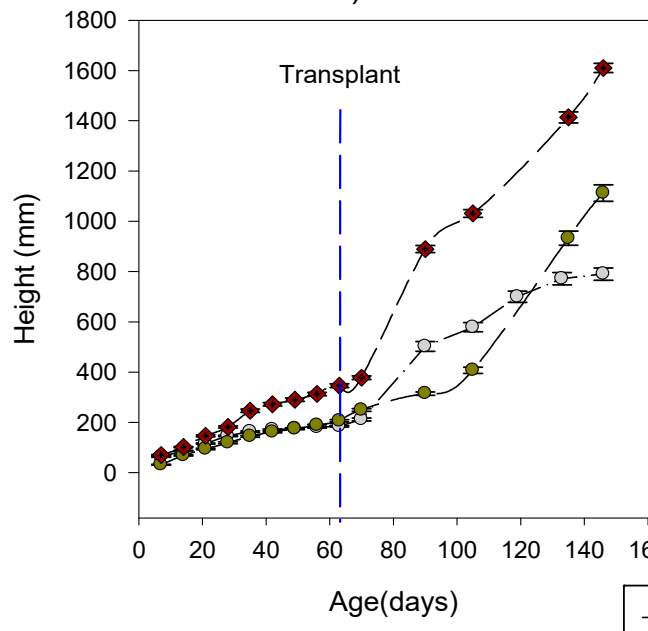

c) Root collar diameter

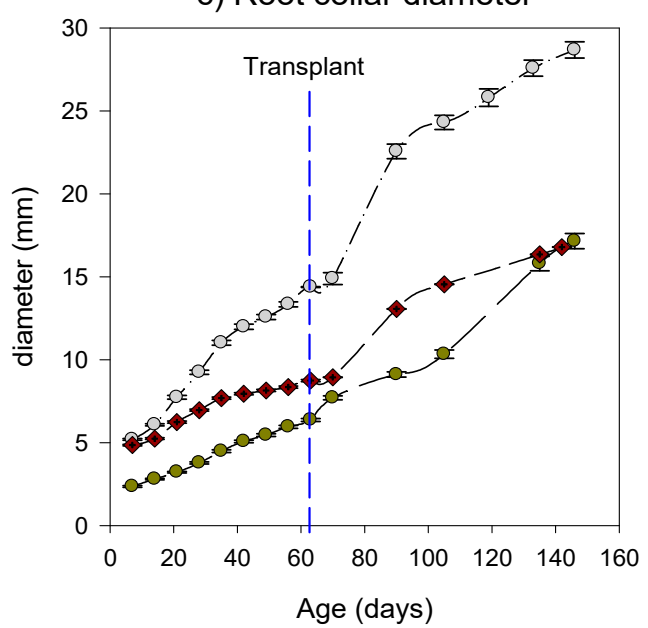

b) Total leaf area

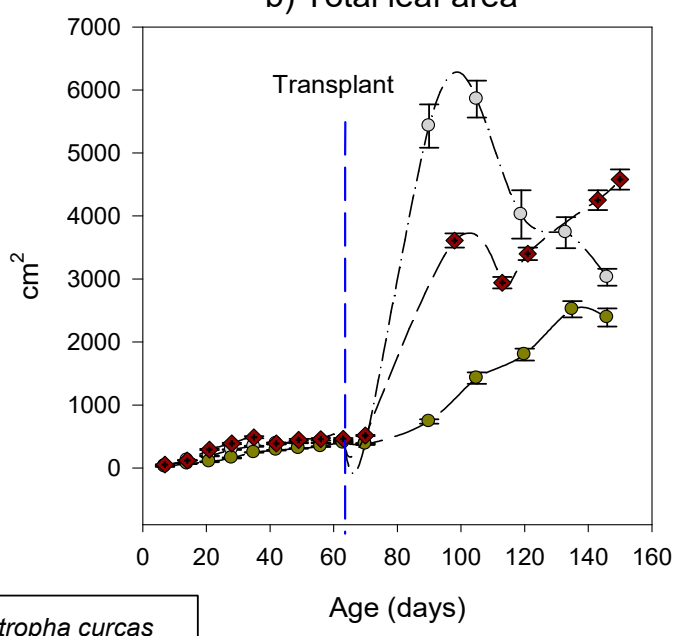

Moringa oleifera

Ricinus communis

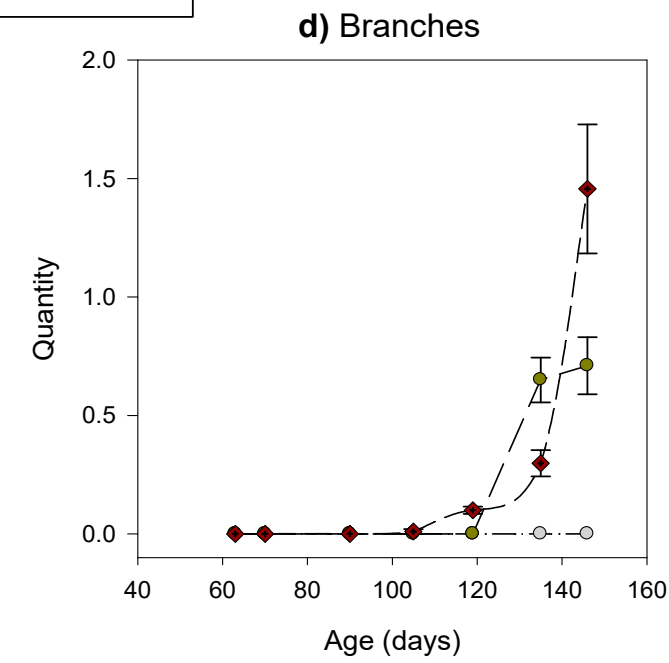

Figure 2. Average growth curves of Jatropha curcas, Moringa oleifera, and Ricinus communis seedlings. (a) Stem height; (b) the total leaf area represents the area of the youngest mature leaf by the number of leaves; (c) diameter at the base of the stem; and (d) branch production. None of the species registered branches before transplant; thus, the dashed vertical line representing the day of transplant was not drawn for this variable at (d). Error bars represent the standard error of the mean. 
Table 5. Mean ( \pm SD) aboveground data of Moringa oleifera, Ricinus communis, and Jatropha curcas, and their environmental conditions documented during previous research at the site.

\begin{tabular}{cccc}
\hline Parameter & Moringa $^{\mathbf{1}}$ & Ricinus $^{\mathbf{1}}$ & Jatropha $^{\mathbf{2}}$ \\
\hline Plant height $(\mathrm{mm})$ & $321.4 \pm 158.0$ & $450.0 \pm 249.7$ & $209.4 \pm 26.6$ \\
RCD & $9.7 \pm 4.1$ & $12.27 \pm 7.0$ & $12.1 \pm 1.6$ \\
Number of leaves & NA & NA & $0.5 \pm 0.7$ \\
Area of average leaf & NA & NA & $4.84 \pm 0.21$ \\
Number of branches & NA & NA & $0.0 \pm 0.0$ \\
Plant age (days) & 103 & 103 & 110 \\
Soil type & Clay & Clay & Sandy \\
Growth conditions & Open field & Open field & Plastic bag $(25 \times 60 \mathrm{~cm})$ \\
Temperature ${ }^{\circ} \mathrm{C}$ & $24.2 \pm 1.5$ & $24.2 \pm 1.5$ & $24.3 \pm 2.7$ \\
Humidity $(\%)$ & $78.4 \pm 5.9$ & $78.4 \pm 5.9$ & $74.3 \pm 12.6$ \\
\hline
\end{tabular}

\subsubsection{Above- and Belowground Relationships}

Belowground measurements are shown in Table 6, while the correlation coefficients between above- and belowground data are shown in Table 7. Figure 3 shows the labeling identification of each measurement. The "trimmed tip" was identified as the limit where roots were cut before transplanting. Ricinus was the species with the highest root elongation before and after trimming, and with the highest number of lateral roots, but it was also the species with the thinnest roots. Moringa had the lowest number of lateral roots and the shortest roots, but it has the thickest roots of the three species.

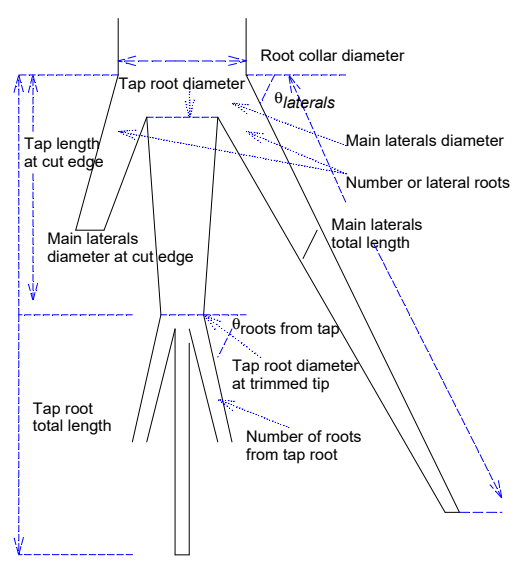

Figure 3. Root measurements taken at tap and main lateral roots indicated in Table 4.

Table 6. Average root dimensions (mm) \pm SE of Moringa oleifera, Ricinus communis, and Jatropha curcas 83 days after root pruning and transplant.

\begin{tabular}{llll}
\hline \multicolumn{1}{c}{ Dimension $(\mathbf{n}=\mathbf{2 0})$} & \multicolumn{1}{c}{ Moringa } & \multicolumn{1}{c}{ Ricinus } & \multicolumn{1}{c}{ Jatropha } \\
\hline Tap root length at trimmed tip & $89.69 \pm 3.42 \mathbf{b}$ & $123.84 \pm 10.63 \mathbf{a}$ & $64.38 \pm 2.67 \mathbf{c}$ \\
Tap root total length & $409.25 \pm 12.82 \mathbf{b}$ & $831.9 \pm 32.36 \mathbf{a}$ & $478.50 \pm 14.10 \mathbf{b}$ \\
Tap root diameter & $58.74 \pm 1.03 \mathbf{a}$ & $10.01 \pm 0.42 \mathbf{c}$ & $28.15 \pm 0.76 \mathbf{b}$ \\
Tap root diameter at trimmed tip & $41.25 \pm 1.96 \mathbf{a}$ & $5.35 \pm 0.34 \mathbf{c}$ & $21.61 \pm 1.10 \mathbf{b}$ \\
Number of roots from tap root & $3.44 \pm 0.21 \mathbf{c}$ & $4.60 \pm 0.40 \mathbf{b}$ & $6.10 \pm 0.32 \mathbf{a}$ \\
Tap root inclination $(\theta$ roots from tap) & $-60.20 \pm 12.19 \mathbf{b}$ & $-81.00 \pm 1.81 \mathbf{a}$ & $-83.71 \pm 1.09 \mathbf{a}$ \\
Number of main lateral roots & $2.00 \pm 0.24 \mathbf{c}$ & $33.37 \pm 2.56 \mathbf{a}$ & $5.60 \pm 0.15 \mathbf{b}$ \\
Main lateral roots total length & $395.19 \pm 12.53 \mathbf{b}$ & $758.58 \pm 33.49 \mathbf{a}$ & $484.55 \pm 22.13 \mathbf{b}$ \\
Main lateral roots diameter & $22.40 \pm 1.16 \mathbf{a}$ & $2.45 \pm 0.12 \mathbf{c}$ & $16.74 \pm 0.78 \mathbf{b}$ \\
Main lateral roots diameter at trimmed tip & $16.78 \pm 1.05 \mathbf{a}$ & $1.03 \pm 0.04 \mathbf{c}$ & $10.64 \pm 0.53 \mathbf{b}$ \\
Lateral root inclination $(\theta$ laterals) & $-53.33 \pm 4.90 \mathbf{a}$ & $-24.25 \pm 2.99 \mathbf{b}$ & $-31.50 \pm 5.34 \mathbf{b}$ \\
Tap root length/stem length & $0.32 \pm 0.01 \mathbf{b}$ & $0.66 \pm 0.02 \mathbf{a}$ & $0.60 \pm 0.01 \mathbf{a}$ \\
Total tap root length/total lateral lengths & $1.04 \pm 0.02 \mathbf{a}$ & $1.11 \pm 0.04 \mathbf{a}$ & $1.00 \pm 0.03 \mathbf{a}$ \\
Root collar diameter/tap root diameter & $0.66 \pm 0.02 \mathbf{b}$ & $1.63 \pm 0.06 \mathbf{a}$ & $1.41 \pm 0.03 \mathbf{a}$ \\
Tap root diameter/main lateral roots diameter & $2.84 \pm 0.13 \mathbf{a}$ & $4.28 \pm 0.27 \mathbf{a}$ & $1.72 \pm 0.05 \mathbf{b}$ \\
Tap root + main lateral roots volume $\left(\mathrm{cm}^{3}\right)$ & $275.69 \pm 19.22 \mathbf{a}$ & $76.89 \pm 5.97 \mathbf{c}$ & $218.24 \pm 27.50 \mathbf{b}$ \\
\hline
\end{tabular}

Different letters in the same row indicate statistical differences $(\mathrm{P}<0.05)$. 
Table 7. Linear correlations between above- and belowground data of Jatropha curcas, Ricinus communis, and Moringa oleifera 83 days after root pruning and transplant.

\begin{tabular}{|c|c|c|c|c|c|c|}
\hline $\begin{array}{l}\text { Species } \\
(n=20)\end{array}$ & Parameter & Height & RCD & $\begin{array}{c}\text { Number of } \\
\text { Leaves }\end{array}$ & Leaf Area & $\begin{array}{c}\text { Number of } \\
\text { Branches }\end{array}$ \\
\hline \multirow{6}{*}{ Jatropha } & Tap root length & $0.61^{* *}$ & $0.58 * *$ & $0.48 *$ & $0.32 *$ & - \\
\hline & Lateral roots length & $0.42 *$ & $0.65 * *$ & $0.44^{*}$ & $0.50 * *$ & - \\
\hline & Tap root diameter & $0.70^{* *}$ & $0.81 * *$ & $0.73^{* *}$ & 0.12 & - \\
\hline & Lateral roots diameter & $0.50 *$ & $0.63 * *$ & $0.61^{* *}$ & 0.05 & - \\
\hline & Number of Laterals & $0.46^{*}$ & $0.44^{*}$ & $0.35^{*}$ & $0.37 *$ & - \\
\hline & Root volume & $0.67^{* *}$ & 0.84 & $0.69 * *$ & 0.25 & - \\
\hline \multirow{6}{*}{ Moringa } & Tap root length & $0.55^{* *}$ & $0.66^{* *}$ & $0.44 *$ & 0.29 & 0.18 \\
\hline & Lateral roots length & $0.40 *$ & $0.53 * *$ & 0.20 & 0.26 & 0.05 \\
\hline & Tap root diameter & $0.76^{* *}$ & $0.80 * *$ & $0.55^{* *}$ & $0.42 *$ & 0.01 \\
\hline & Lateral roots diameter & 0.13 & 0.15 & 0.27 & -0.21 & 0.21 \\
\hline & Number of Laterals & $0.66^{* *}$ & $0.76^{* *}$ & $0.58 * *$ & 0.21 & 0.20 \\
\hline & Root volume & $0.76^{* *}$ & $0.76^{* *}$ & $0.59^{* *}$ & 0.32 & 0.12 \\
\hline \multirow{6}{*}{ Ricinus } & Tap root length & $0.57^{* *}$ & 0.23 & 0.25 & -0.20 & 0.09 \\
\hline & Lateral roots length & $0.30 *$ & 0.22 & $0.30 *$ & -0.13 & 0.12 \\
\hline & Tap root diameter & 0.03 & $0.51 * *$ & 0.16 & 0.00 & $0.26^{*}$ \\
\hline & Lateral roots diameter & $0.34^{* *}$ & 0.21 & 0.12 & 0.06 & -0.07 \\
\hline & Number of lateral roots & 0.06 & -0.12 & -0.08 & 0.17 & -0.02 \\
\hline & Root volume & $0.43^{* *}$ & $0.42 * *$ & 0.24 & 0.15 & 0.10 \\
\hline
\end{tabular}

** Significant at $0.05 ; *$ significant at 0.01 . - The stem of Jatropha did not develop branches.

Figure 4 shows the digitized roots of Jatropha, Moringa, and Ricinus. For the three species, trimming of tap roots induced the formation of new root branches at the trimmed limbs. The new root branches emerging from the tap root had average inclinations of $-82^{\circ}$ for Ricinus and Jatropha, and $-60^{\circ}$ for Moringa.

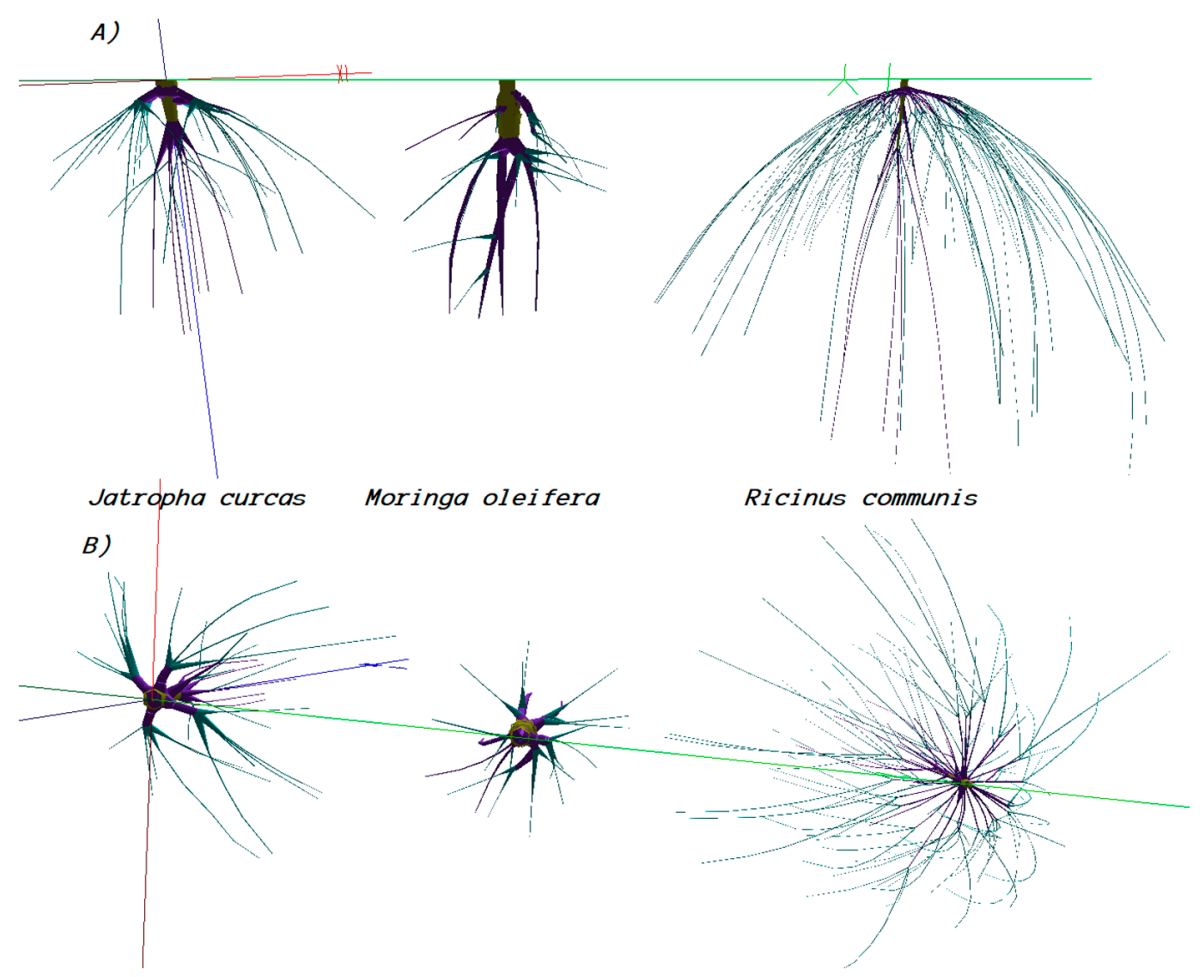

Figure 4. Roots of Jatropha, Moringa, and Ricinus digitized 83 days after their root pruning and transplant.

(A) Vertical projection; (B) Horizontal projection. 


\subsubsection{Root Distributions and Their Models}

Root volume distribution indicated that Moringa had the highest volume distributed around the first $10 \mathrm{~cm}$ of its stem, although its root volume decreased rapidly along horizontal and vertical surfaces (Figure 5). Jatropha and Ricinus had their highest volume distributed along the first $5 \mathrm{~cm}$ around the stump. Ricinus had the lowest root volume decrement along its vertical and horizontal distribution. Moringa the thickest tap root and the highest number of roots with the thickest diameters, but its roots were the shortest of the three species. Ricinus had the highest number of roots with the smallest diameters and the longest roots along vertical and horizontal surfaces.
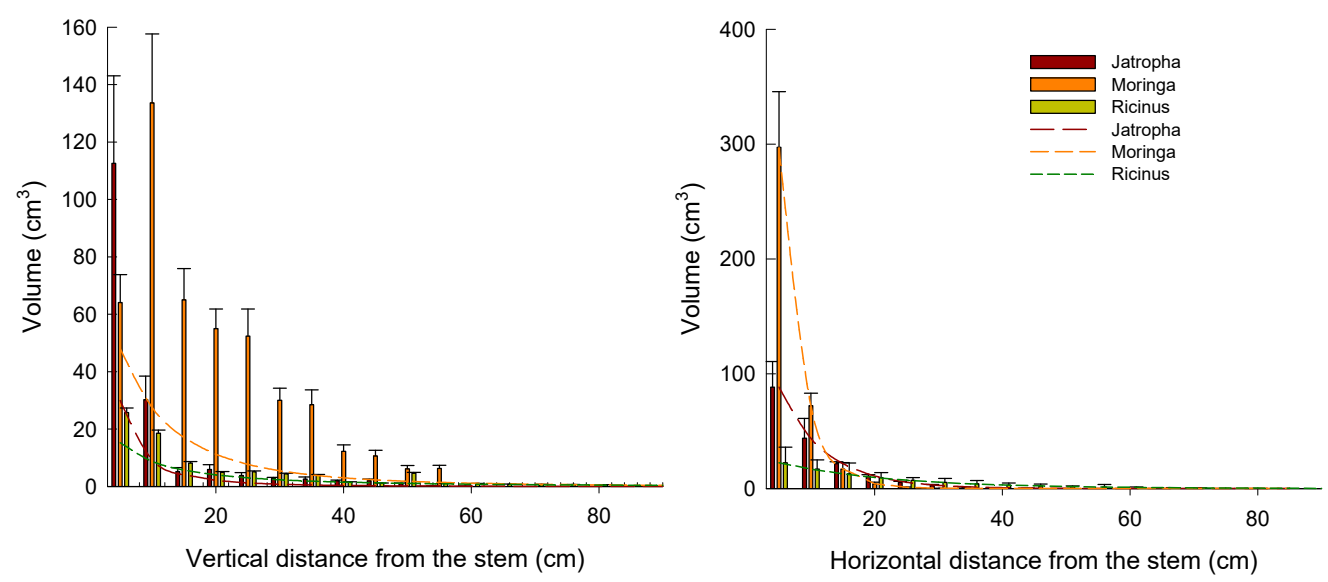

Figure 5. Root volume distribution of Jatropha, Moringa, and Ricinus 83 days after root pruning and transplanting. Vertical error bars represent the standard error of the mean. The dashed lines represent the estimated models.

Root distribution models were best fitted by logistic models for the vertical distribution and by exponential models for the horizontal distribution. The parameters obtained for each model and their corresponding $\mathrm{r}^{2}$ and square sums (SS) are shown in Table 8.

Table 8. Root distribution models of Jatropha curcas, Moringa oleifera, and Ricinus communis 83 days after root pruning and transplanting.

\begin{tabular}{|c|c|c|c|c|}
\hline & Parameters and Model & Jatropha & Moringa & Ricinus \\
\hline $\begin{array}{c}\text { Vertical } \\
\text { distribution }\end{array}$ & $\begin{array}{l}\text { Vertical root volume }\left(\mathrm{cm}^{3}\right) \\
\text { at a distance D } \\
\text { SS } \\
\mathrm{r}^{2}\end{array}$ & $\begin{array}{c}\frac{181.20}{1+\left(\frac{D}{58.77}\right)^{3.09}} \\
37.64 \\
0.99\end{array}$ & $\begin{array}{c}\frac{92.64}{1+\left(\frac{D}{248.60}\right)^{3.59}} \\
3195.32 \\
0.85\end{array}$ & $\begin{array}{c}\frac{33.58}{1+\left(\frac{D}{97.22}\right)^{1.91}} \\
26.40 \\
0.97\end{array}$ \\
\hline $\begin{array}{l}\text { Horizontal } \\
\text { distribution }\end{array}$ & $\begin{array}{c}\text { Horizontal root volume }\left(\mathrm{cm}^{3}\right) \\
\text { at a distance } \mathrm{D} \\
\mathrm{SS} \\
\mathrm{r}^{2}\end{array}$ & $\begin{array}{c}178.50 e^{-0.014 D} \\
710.21 \\
0.93\end{array}$ & $\begin{array}{c}676.60 e^{-0.02 D} \\
1.38 \\
0.99\end{array}$ & $\begin{array}{c}29.88 e^{-0.006 D} \\
26.35 \\
0.96\end{array}$ \\
\hline
\end{tabular}

$\mathrm{D}=$ distance from the base of the stump $(\mathrm{cm}) ; \mathrm{r}^{2}=$ coefficient of determination; SS = square sum.

\subsection{Plant Fresh and Dry Weight}

Moringa had the heaviest fresh and dry roots of the three species, while Jatropha had the heaviest fresh and dry stem and total weight of the three species $(\mathrm{P}<0.05)$. Ricinus had the lightest fresh and dry roots of the three species, as it had the lightest total weight of the three species (Table 9). 
Table 9. Average ( \pm SE) fresh and dry weight $(\mathrm{g})$ of Moringa oleifera, Ricinus communis, and Jatropha curcas 83 days after root pruning and transplanting.

\begin{tabular}{cccc}
\hline Parameter $(\mathbf{n}=\mathbf{2 0})$ & Moringa & Ricinus & Jatropha \\
\hline Leaf fresh weight & $63.72 \pm 7.70 \mathbf{b}$ & $74.83 \pm 3.41 \mathbf{a}$ & $75.10 \pm 1.85 \mathbf{a}$ \\
Stem fresh weight & $127.19 \pm 12.76 \mathbf{b}$ & $136.00 \pm 5.06 \mathbf{b}$ & $187.91 \pm 5.78 \mathbf{a}$ \\
Root fresh weight & $136.78 \pm 11.85 \mathbf{a}$ & $75.16 \pm 3.87 \mathbf{b}$ & $59.03 \pm 1.83 \mathbf{c}$ \\
Above/below ground fresh weight & $1.42 \pm 0.07 \mathbf{c}$ & $2.92 \pm 0.37 \mathbf{b}$ & $4.84 \pm 0.21 \mathbf{a}$ \\
Leaf dry weight & $12.07 \pm 1.40 \mathbf{b}$ & $9.37 \pm 0.41 \mathbf{c}$ & $14.10 \pm 0.12 \mathbf{a}$ \\
Stem dry weight & $26.48 \pm 2.12 \mathbf{b}$ & $20.17 \pm 0.77 \mathbf{b}$ & $81.67 \pm 3.29 \mathbf{a}$ \\
Root dry weight & $19.69 \pm 1.89 \mathbf{a}$ & $7.54 \pm 0.37 \mathbf{c}$ & $12.54 \pm 0.40 \mathbf{b}$ \\
Above/below ground dry weight & $2.14 \pm 0.15 \mathbf{c}$ & $4.01 \pm 0.15 \mathbf{b}$ & $7.65 \pm 0.18 \mathbf{a}$ \\
\hline
\end{tabular}

Different letters in the same row indicate statistical differences $(\mathrm{P}<0.05)$.

\subsection{Allometric Relationships for Above- and Belowground Biomass Estimation}

Table 10 shows the models with the highest coefficients of regression between allometric data and above- and belowground biomass estimation.

Table 10. Biomass estimation of Moringa, Ricinus, and Jatropha by their allometric relationships.

\begin{tabular}{|c|c|c|c|}
\hline Biomass (mg) & Moringa & Ricinus & Jatropha \\
\hline \multicolumn{4}{|l|}{$L=$ Leaf } \\
\hline Variables & $\mathrm{HNA}=\mathrm{H} \mathrm{N} \mathrm{A}$ & $\mathrm{HNA}=\mathrm{H}$ N A & $\mathrm{NA}=\mathrm{NA}$ \\
\hline Model & $\mathrm{L}=-1.8+10.3 \ln (\mathrm{HNA})$ & $\mathrm{L}=15.3(\mathrm{HNA})^{0.6}$ & $\mathrm{~L}=17.7+3.8 \ln (\mathrm{NA})$ \\
\hline Type & Logarithm & Power & Logarithm \\
\hline $\mathrm{r}^{2}$ & 0.83 & 0.67 & 0.57 \\
\hline SS & 106.6 & 47.8 & 9.8 \\
\hline \multicolumn{4}{|l|}{$\mathrm{S}=$ Stem } \\
\hline Variables & $\mathrm{HNA}=\mathrm{H} \mathrm{N} \mathrm{A}$ & $\mathrm{DH}=\mathrm{DH}$ & $\mathrm{D}$ \\
\hline Model & $\mathrm{S}=5.4+15.8 \ln (\mathrm{HNA})$ & $\mathrm{S}=540(\mathrm{DH})^{0.84}$ & $S=267.1+59.6 \ln (D)$ \\
\hline Type & Logarithm & Power & Logarithm \\
\hline $\mathrm{r}^{2}$ & 0.87 & 0.70 & 0.54 \\
\hline SS & 187.5 & 138.9 & 1733.2 \\
\hline \multicolumn{4}{|l|}{$R=$ Root } \\
\hline Variables & $\mathrm{HNA}=\mathrm{H} \mathrm{N} \mathrm{A}$ & $\mathrm{DH}=\mathrm{DH}$ & DNA = D N A \\
\hline Model & $\mathrm{R}=2.9+12.7 \ln (\mathrm{HNA})$ & $\mathrm{R}=182.6(\mathrm{DH})^{0.81}$ & $\mathrm{R}=67.1 \mathrm{DNA}^{0.40}$ \\
\hline Type & Logarithm & Exponential & Power \\
\hline $\mathrm{r}^{2}$ & 0.71 & 0.41 & 0.57 \\
\hline SS & 328.6 & 61.9 & 36.1 \\
\hline
\end{tabular}

$\mathrm{H}=$ height $(\mathrm{m}) ; \mathrm{D}=\mathrm{RCD}(\mathrm{m}) ; \mathrm{N}=$ Number of leaves; $\mathrm{A}=$ Area of average leaf $\left(\mathrm{m}^{2}\right) ; \mathrm{r}^{2}=$ coefficient of determination; $\mathrm{SS}=$ square sum.

\section{Discussion}

\subsection{Germination and Survival}

Results from this experiment indicated that Ricinus can propagate faster and had a greater survival than Jatropha and Moringa in these subtropical conditions (warm sub-humid climate and 5:1 sand/compost substratum). In this regard, Ricinus was the most adaptable species, with higher plasticity to respond to different environmental conditions [31], which is confirmed by the fact that these seeds came from a drier site (Bsh climate), and they had 100\% germination rate in a higher environmental humidity (sub-humid climate), performing even better than seeds of Jatropha, that come from a similar climate as the experimental site. Moringa was the species with the lowest capabilities to propagate and survive due to its having the lowest germination and survival rate combined with the longest mean germination time over this and previous experiments, even though the seeds came from plants located in a similar climate (Aw). Studies over Moringa seed germination found that temperatures above $20^{\circ} \mathrm{C}$ 
significantly increase mean germination time and germination rate; thus they consider that a good germination performance is highly dependent on warm temperatures. However, even with fresh seeds, the germination percentages reported by different investigations were below $90 \%$ [18,32]. During this experimental period, the site had average temperatures $4.4^{\circ} \mathrm{C}$ lower than the ones recorded during the previous experiments. These temperatures could also have affected germination speed, which was slower compared to previously reported experiments for the three species. We observed that seeds of Moringa that did not germinate and plants that did not survive had problems with fungi. In this regard, we consider that the higher humidity and organic contents in the substratum were detrimental for Moringa, since it is a species adapted to very arid soils [4], and it may lack defenses against pathogens living in these environments. We also found that for the three species, heavy substrata are detrimental for a good propagation and germination speed (Table 1), especially for Jatropha, which registered the lowest average germination in the site. Jatropha's germination problems are related to its thick testa, the thickest of the three species, and its innate vegetative rest. Nevertheless, the substratum with added compost used in this experiment aided in increasing the permeability of the testa, which helped to hydrate the embryo, resulting in an improvement of the germination rate [33]. Thus, the mix of $5: 1 \mathrm{sand} /$ compost in the substratum of this experiment provided nutrients to improve robustness of the sprouts, facilitating good propagation of the three species $[29,33]$, which are mostly adapted to light soils $[4,7]$.

Considering temperatures and substrata, in terms of the capacity of establishment, Ricinus was the most successful species.

\subsection{First Phase of Seedling Growth}

\subsubsection{Stem Growth Rates}

For the first growing phase, the highest growing rates of Ricinus over Jatropha and Moringa were similar to the ones reported by previous experiments at the site, and the same as the highest RCD growth rates and the lowest slenderness found in Jatropha. This behavior confirms Ricinus as the most pioneering species of the three. Jatropha, with thicker stems and lower slender indexes, reflects a strong adaptation to dry environments, storing resources at the base of its stem [34]. It is important to remark, here, that this subtropical site has a pronounced dry season that can last up to five or six months; thus, native trees and shrubs, like Jatropha, have developed morphological adaptations to deal with this dry period [35]. Moringa represented a different strategy to cope with arid places because it developed the thinnest stem (Figure 1), but also 11\% higher elongation rates than Jatropha. This behavior gave Moringa an advantage for light competition over Jatropha, but without expending as many resources as the other species in its aboveground development.

\subsubsection{Leaf Production}

Moringa attracted attention for its highest leaf production during the last 30 days of the two months after sprouting. Previous data show that Moringa always produced more leaves than Ricinus and Jatropha, even in poor sandy soils (Table 2). This characteristic of Moringa is an inherent ability of the species linked to arid soils [4]. The compound leaves of Moringa, which are thinner and have lighter blades, are also related to a lower energetic investment [36]; therefore, they can be produced faster than the ones of Ricinus and Jatropha, giving Moringa advantages for better plant development in the long term.

\subsubsection{Root Systems and Their Relationships with Aboveground Growth Patterns}

The longest and more numerous branches of Ricinus roots point towards its highest capacity to explore and obtain resources from its environment. Morphologically, Ricinus roots are linked to faster plant development [37]. Thus, the highly significant correlation between root volume and leaf 
area during its early growing phase confirmed that root development is aimed at increasing its photosynthetic capacity and, as a result, Ricinus had the largest leaves of the three species.

During this early phase, Moringa and Jatropha had statistically similar root volumes $(\mathrm{P}=0.79)$, which were two times the volume of the roots of Ricinus. However, they differed in their root morphology and in the distribution of their reserves. Moringa stood out for its thickest napiform root since its first two months after sprouting, which represents its particular strategy to store reserves belowground which started at the first phase of growth. In this way, it can tolerate dry periods or being damaged aboveground and survive [38,39]. The highly significant correlation between leaf area and stem height indicates that Moringa was using its photosynthetic organs with emphasis in producing belowground reserves. On the other hand, the highest correlation between RCD and root volume in Jatropha indicates that this species uses its roots to search for resources and store them at the base of its stem, which is a characteristic of stem succulent species from dry environments [38].

\subsection{Second Phase: Plant Performance after Transplanting}

\subsubsection{Survival Rate and Aboveground Growth}

The fact that the three species had 100\% survival rate and very good development just 30 days after severe root pruning and bare root transplanting (Figure 2) indicate that these species are robust enough to survive and recover from transplant shock. We make this assumption because plants without transplant from previous experiments at the site, but under different soil types, reached smaller values of heights and RCDs. The higher development of the three species here can be explained by the $20 \%$ compost that integrated the substratum, which helped to increase plant size, due to its good percentage of N. Studies of Moringa indicate that this species can increase its biomass 1.9 times if $2.5 \% \mathrm{~N}$ is added to the soil [40], and in this experiment its height was increased by $246 \%$ and its RCD by $77 \%$. For Ricinus, $4.1 \% \mathrm{~N}$ could increase plant height 1.6 times and plant biomass 2.2 times [41], and in this experiment, it increased height by $258 \%$ and RCD by $37 \%$. For Jatropha, application of only $0.20 \% \mathrm{~N}$ can increase plant height 1.8 times and RCD 1.2 times [42]. These data are compatible with the highest increment in height (277\%) and RCD (137\%) for Jatropha, meaning that, aboveground, Jatropha obtained the highest advantage of increased soil nutrition. Thus, we recommend the amendment of compost to arid soils for good development of the three species.

Considering previous studies (Table 2), it is remarkable that even in heavy soils, Ricinus always obtained higher stem elongation, while Jatropha had the slowest growth rates. Considering that irrigation was constantly provided, Moringa and Ricinus used the available water and nutrients to accelerate their growth, as observed by the increments in their elongation and branches; instead of this strategy, Jatropha used these resources with a major focus in storing them at the base of its stump. This behavior can be noted because this was the species with the thickest RCD, the highest moisture content (44\% more than Moringa and 59\% more than Ricinus), and the densest stem of the three species. The slowest stem elongation rates and the lowest branching formation of Jatropha place this plant as the one with slowest development of the three species but, at the same time, it was the one with the highest dry avoidance capabilities during its early growing phase [38].

\subsubsection{Plant Defoliation}

Plant defoliation after transplanting was caused from root loss, which decreased the ability to absorb water and nutrients and decreased the reserves of these compounds located at the roots, such as carbohydrates, minerals, and water [9]. In this regard, Moringa was more affected by transplant shock than Jatropha and Ricinus because Moringa had the highest defoliation. Moringa had the highest root volume, but also had higher tap root diameter than RCD, which means this species was storing more resources belowground than aboveground, contrary to Jatropha and Ricinus, which stored more reserves in their stems. Therefore, trimming of roots could more greatly affect its reserves system to avoid stressful situations, which is one strategy of this species [38], triggering leaf senescence as a result 
of higher nutrient deficiencies and water stress. Besides this, the thicker leaves of Jatropha and Ricinus are considered to be drought-resistant $[43,44]$ and, therefore, they were able to resist transplant shock with lower or null defoliation, like Jatropha, which also had the thickest leaves. In this regard, we can remark that leaf thickness was correlated with plant defoliation, being the species with the thinnest leaves and highest defoliation percentage.

\subsubsection{Branching and Flowering}

A comparison of the three species show that Ricinus was the one with the fastest development, since its plants produced the highest number of branches and reached maturity in a period similar to the one reported for this genotype at the site, which is around 150 days [28]. For the case of Jatropha and Moringa, it has been documented that they require 12 or more months to mature [45]. Therefore, the lack of flowers in both species was normal at this stage and we could not evaluate this phase during this experimental period. Nevertheless, plant growth recorded in this experiment was similar or even greater than previously reported at the site. Thus, we can assume that root trimming and transplant in these species may not cause considerable delay in reaching maturity.

\subsection{Second Phase: Belowground Development}

\subsubsection{Root Distribution and Root Distribution Models}

Pruning roots resulted in the formation of new tap and lateral trimmed roots for the three species. Jatropha and Moringa had higher new roots than Ricinus, because their root diameters where thicker than the ones of Ricinus and, therefore, their trimmed root area for the formation of more branches was higher. The inclination angles (greater than $-60^{\circ}$ ) of the new tap roots in the three species indicate that these new branches were acting as anchors to increase plant stability [16]. The lower inclination angles of Moringa roots can be associated with their thicker size, although these inclination angles are high enough to perform an anchorage role [20]. Consequently, root pruning did not decrease anchoring capabilities, with the increment in the number of roots being beneficial for their structure, as we theorized before the experiment.

In the horizontal distribution of roots, Moringa stood out for its highest volume distribution (74\%) along the first $5 \mathrm{~cm}$ around the stump (Figure 5), which is the result of the napiform shape of its tap and lateral roots. The vertical root distribution of Moringa had a very characteristic distribution along the soil, resembling a Gaussian curve, which was best represented by a logistic model explaining $85 \%$ of variation, where the highest volume (31\%) was located $10 \mathrm{~cm}$ below the surface because this species locates its reserves at a certain distance belowground as a safety measure to avoid damage [14].

Jatropha distributed $50 \%$ of its root volume in the first $5 \mathrm{~cm}$ along its stump horizontally, and $68 \%$ vertically. Root volume decay along the vertical surface was slightly lower than Moringa, but higher than Ricinus, and the logistic model was able to explain $99 \%$ of variation.

Ricinus distributed only $34 \%$ of its volume in the first $5 \mathrm{~cm}$ below the surface, and $27 \%$ in the first $5 \mathrm{~cm}$ around its stump. This species had the smoothest vertical and horizontal distribution, and the models representing this performance had the slowest decay speed, especially along the horizontal distribution.

Similar horizontal and vertical root distribution models were obtained for one-year-old plants of Moringa and Ricinus growing under a clay soil [14]. This means that these Moringa and Ricinus seedlings show analogous distribution patterns as adult plants without transplant. Therefore, we consider that trimming of roots did not substantially change the natural behavior of their root distribution. We did not find any model for Jatropha and, therefore, this is the first model to be presented; nevertheless, this study has found that Jatropha has a root distribution similar to Ricinus, while Moringa follows a completely different pattern. 


\subsubsection{Root Trays and Their Implications for Aboveground Development}

Root trays indicate that the highest capacity to cover soil along horizontal and vertical surfaces was obtained by Ricinus, which has the highest capacity of soil exploration and cohesion [31], followed by Jatropha and, with the lowest capacity, Moringa. Therefore, we consider that Ricinus could be more successful than Jatropha or Moringa if transplanted in eroded or loose soils. The higher number and longer extension of Ricinus lateral roots indicate its greater capacity to recover more quickly from transplant compared to the others. Small diameters and considerably longer and numerous roots are traits associated with maintaining plant productivity under drought stress, because longer and thinner roots are able to reach more resources for a lower energy investment [36]. This performance can be observed in the plant weight distribution, because Ricinus had the lightest fresh and dry weight roots of the three species, maintaining similar fresh and dry weights of stem compared to Moringa, which had the heaviest roots. Prior to transplant, the three species had the same root trays, with Ricinus having the most extensive root system, Jatropha moderate, and Moringa the most compact. Therefore, we considered that the natural root distribution patterns of the three species did not change with root pruning and transplant.

In the second phase, the root volume of Ricinus correlations more strongly with stem height and RCD than leaf area, which did not significantly correlate with root parameters. This indicates that stem elongation is highly dependent on root development. We found that plants with thicker tap roots had significant correlations with the number of branches, and the plants with longer roots were the ones that were flowering earlier; therefore, we can state that these root trays play an important role in plant maturation for Ricinus [28].

Jatropha followed Ricinus in root covering, but it developed only $29 \%$ of the number of root branches of Ricinus, although it had 58\% more branches than Moringa, and almost three times longer roots than Moringa. Like Ricinus, Jatropha produced more biomass in its stem than in its roots, but these roots were heavier and thicker compared to Ricinus. Thus, we state that Jatropha benefited from root pruning because this species usually does not develop highly branched roots during its juvenile stage [11], and the number of roots increased more than six times after this treatment. Other research of three-year-old plants indicate that this species can grow fine roots of greater lengths in the surface soil [46], same as are found in juvenile plants, but it has a conservative root system, which means that these roots will not be as good as the ones of Ricinus at capturing nutrients and water; consequently, plant development of Jatropha is slower. However, Jatropha had the strongest relationship between root volume and RCD and number of leaves, which means that this species will depend more on its root development than the other two species to store resources at the base of its stem and to increase its photosynthetic capabilities.

Moringa, with the thickest and shortest roots, was the species with the lowest soil covering capacity, although it developed the longest thicker roots and the heaviest root system, with even longer tap elongation at the trimmed tip than Jatropha. Correlations between below- and aboveground parameters indicate that, during the second growth phase, Moringa initiated storing resources at the base of its stump as a stem caudiciform species [38], similarly to Jatropha since its early phase. Moreover, Moringa allocated more water and biomass to its roots than its other organs, which is a typical characteristic of the species [14]. Therefore, we consider that transplanting did not affect its natural biomass distribution. In addition, by the end of the experimental period, the three species were developing faster than other ones without transplant reported at the site. Thus, we can say that after the recovery time, increases in root density had a positive influence over plant development.

\subsubsection{Above- and Belowground Biomass Estimation by Allometric Data}

The models obtained in this experiment indicate that allometric relationships differed among species, with each one depending on different allometric measurements for estimated biomass fractions (leaves, stem, and roots). Studies with small trees and shrubs have found that height and RCD are the main parameters used to estimate aboveground biomass [24], as we have confirmed in this study 
in the case of Ricinus, whose equations for estimating stem and root biomass involved height and RCD; nevertheless, in the case of Moringa and Jatropha, we must to consider that plants at this juvenile stage do not have the same biomass partitions as their adults and, therefore, leaf area played a more important role for their biomass estimation.

In adult trees of Moringa, the RCD instead of the height of the stem is a better estimator for biomass partitions; however, for adult Ricinus, height and RCD are used together to estimate biomass [14], while for Jatropha, crown diameter, height, and RCD are required [17]. Thus, we consider that for Ricinus, the size of the stem is the most important characteristic for estimating biomass during its early development, while in Jatropha, leaf data is the most important parameter to estimate biomass. Considering weight distribution, we noticed that Jatropha had the lowest investment in root biomass for develop the highest stem biomass. This relationship can be a consequence of Jatropha being a stem succulent species [44], which depends more on its stem to avoid drought than Moringa or Ricinus. The allometric relationships of the three species indicate that they maintained their natural biomass partition after pruning and transplant, recovering from the shock in less than 83 days, which is a shorter time compared with other perennial species that required more than 100 days [11].

\section{Conclusions}

Among the three oily species, Ricinus was the species with the highest capacity to survive and propagate in a subtropical climate with light substratum.

Trimming of roots increased plant stability in the soil because it induced higher root branching in the three species, especially for Jatropha and Moringa, which normally develop a low number of branches during the early stage.

Root pruning did not affect plant behavior, with Ricinus being the species with the most efficient root system, characterized by long thin roots linked to the fastest shoot development before and after transplant. Moringa, with the thickest and shortest roots, maintained its strategy to store reserves belowground and at the base of its stump, while Jatropha, with shorter and thicker roots than Ricinus, was the species with the slowest aboveground development, focusing mostly in storing reserves at the base of its stump.

The allometric models indicated that the best predictor for Jatropha's biomass was its root collar diameter, while the best estimators for Ricinus and Moringa were their stem heights and leaf area.

Among the three, Ricinus was the earliest successional species, followed by Moringa, and Jatropha was the most recent successional species.

Author Contributions: Conceptualization, methodology, writing, editing and supervision, O.A.V.-R. Facilities and project management, drafts editing, A.P.-V.

Funding: This research received support of CONACYT for the postdoctorate scholarship of the first author.

Acknowledgments: Authors want to thank Dra. Olga Reyes by her support reviewing English grammar of this manuscript.

Conflicts of Interest: The authors declare no conflict of interest.

\section{References}

1. Velázquez-Zavala, M.; Peón-Escalante, I.E.; Zepeda-Bautista, R.; Jiménez-Arellanes, M.A. Moringa (Moringa oleifera Lam.): Usos potenciales en la agricultura, industria y medicina. Rev. Chapingo Ser. Hortic. 2016, 22, 95-116. [CrossRef]

2. Clixoo, S. Comprehensive Castor Oil Report; Energy Alternatives India: Gujarat, India, 2016; Available online: http://www.eai.in/ref/reports/castor_oil_comprehensive_report.html (accessed on 10 June 2019).

3. Becker, K.; Makkar, H.P.S. Jatropha curcas: A potential source for tomorrow's oil and biodiesel. Lipid Technol. 2008, 20, 104-107. [CrossRef]

4. Parrotta, J. Moringa oleifera. In Enzyklopädie der Holzgewächse; Roloff, A., Weisgerber, H., Lang, U., Stimm, B., Eds.; Wiley-Vch: Weinheim, Germany, 2009; pp. 1-8. ISBN 9783527321414. 
5. Solís, B.J.L.; Zamarripa, C.A.; González, A.A.; Rico, P.H.R.; Tapia, V.L.M.; Teniente, O.R.; Zacarías, G.M.; Cruz, R.J.R.; Hernández, M.M. Guía Técnica para la Producción de Higuerilla (Ricinus communis L.) en Chiapas, 1st ed.; Instituto Nacional de Investigaciones Forestales, Agrícolas y Pecuarias: Tuxtla, Mexico, 2011.

6. Achten, W.M.J.; Nielsen, L.R.; Aerts, R.; Lengkeek, A.G.; Kjaer, E.D.; Trabucco, A.; Hansen, J.K.; Maes, W.H.; Graudal, L.; Akinnifesi, F.K.; et al. Towards domestication of Jatropha curcas. Biofuels 2010, 1, 91-107. [CrossRef]

7. Valdés Rodríguez, O.A.; Pérez Vázquez, A.; García Pérez, E.; Inurreta Aguirre, H.D. Condiciones agroecológicas de procedencias nativas de Jatropha curcas L. In Energía Alterna y Biocombustibles; Perez Vazquez, A., Garcia Perez, E., Eds.; Colegio de Postgraduados: Montecillo, Mexico, 2013; pp. 143-152. ISBN 9786077151043.

8. SDA, (Secretaría de Desarrollo Agropecuario). Manual de Reforestación, 1st ed.; SDA, (Secretaría de Desarrollo Agropecuario), Ed.; Gobierno del Estado de México: Toluca, Mexico, 2006; ISBN 8495458233.

9. Struve, D.K. Tree establishment: A review of some of the factors affecting transplant survival and establishment. Arboric. Urban. 2009, 35, 10-13.

10. Gao, K.; Zhu, T.; Wang, L.; Gao, Y. Effects of root pruning radius and time on yield of tuberous roots and resource allocation in a crop of Helianthus tuberosus L. Sci. Rep. 2018, 8, 1-7. [CrossRef] [PubMed]

11. Benson, A.R.; Morgenroth, J.; Koeser, A.K. The effects of root pruning on growth and physiology of two Acer species in New Zealand. Urban For. Urban Green. 2018, 38, 64-73. [CrossRef]

12. Bailey, P.H.J.; Currey, J.D.; Fitter, A.H. The role of root system architecture and root hairs in promoting anchorage against uprooting forces in Allium cepa and root mutants of Arabidopsis thaliana. J. Exp. Bot. 2002. [CrossRef] [PubMed]

13. Comas, L.H.; Bouma, T.J.; Eissenstat, D.M. Linking root traits to potential growth rate in six temperate tree species. Oecologia 2002, 132, 34-43. [CrossRef]

14. Valdés-Rodríguez, O.A.; Giadrossich, F.; Pérez-Vázquez, A.; Moreno-Seceña, J.C. Above- and below-ground biomass and allometry of Moringa oleifera and Ricinus communis grown in a compacted clayey soil. Flora 2018, 241, 35-45. [CrossRef]

15. Smith, G.D.; Jangawad, L.; Grivastava, K. Castor roots in a vertic inceptisol. In Development in Agricultural and Management Forest Ecology; Elsevier: Amsterdam, The Netherlands, 1991; Volume 24, pp. 533-543.

16. Valdés-Rodríguez, O.A.; Sánchez-Sánchez, O.; Pérez-Vázquez, A.; Caplan, J.S.; Danjon, F. Jatropha curcas L. root structure and growth in diverse soils. Sci. World J. 2013, 2013, 1-9. [CrossRef] [PubMed]

17. Bayala, R.; Hernandez, R.R.; Diédhiou, I.; Mbengue, A.A.; Diallo, D.; Sène, A.; Diédhiou, P.M.; Diémé, R. Allometric equations and carbon stocks in tree biomass of Jatropha curcas L. in Senegal's Peanut Basin. Glob. Ecol. Conserv. 2016, 9, 61-69.

18. Muhl, Q.E. Seed Germination, Tree Growth and Flowering Responses of Moringa oleifera Lam. (Horseradish tree) to Temperature. Ph.D. Thesis, University of Pretoria, Pretoria, South Africa, 2009.

19. Ghestem, M.; Veylon, G.; Bernard, A.; Vanel, Q.; Stokes, A. Influence of plant root system morphology and architectural traits on soil shear resistance. Plant Soil 2014, 377, 43-61. [CrossRef]

20. Reubens, B.; Achten, W.M.J.; Maes, W.H.; Danjon, F.; Aerts, R.; Poesen, J.; Muys, B. More than biofuel? Jatropha curcas root system symmetry and potential for soil erosion control. J. Arid Environ. 2011, 75, 201-205.

21. Liv Soares, S.; Silva Do Vale, L.; De Macedo Beltrao, N.E. A simple Method for Measurement of Jatropha curcas Leaf Area. Rev. Bras. Oleag. Fibr. 2007, 11, 9-14.

22. Jain, T.C.; Misra, D.K. Leaf area estimation by linear measurements in Ricinus communis. Nature 1966, 212, 741-742. [CrossRef]

23. GFORGE-INRIA. Openalea-OpenAlea. Available online: http://openalea.gforge.inria.fr/dokuwiki/doku. php?id=openalea (accessed on 2 March 2016).

24. Ali, A.; Xu, M.S.; Zhao, Y.T.; Zhang, Q.Q.; Zhou, L.L.; Yang, X.D.; Yan, E.R. Allometric biomass equations for shrub and small tree species in subtropical China. Silva Fenn. 2015, 49, 1-10. [CrossRef]

25. Achten, W.M.J.M.J.; Maes, W.H.H.; Reubens, B.; Mathijs, E.; Singh, V.P.P.; Verchot, L.; Muys, B. Biomass production and allocation in Jatropha curcas L. seedlings under different levels of drought stress. Biomass Bioenergy 2010, 34, 667-676. [CrossRef]

26. Sinacore, K.; Hall, J.S.; Potvin, C.; Royo, A.A.; Ducey, M.J.; Ashton, M.S. Unearthing the hidden world of roots: Root biomass and architecture differ among species within the same guild. PLoS ONE 2017, 12, 1-22. [CrossRef] [PubMed] 
27. Valdés-rodríguez, O.A.; Pérez-vázquez, A.; Muñoz-Gamboa, C. Efecto de peso y talla de semilla sobre plántulas de Moringa y Ricinus. Rev. Mex. Cienc. Agrícolas 2018, 9, 1411-1422. [CrossRef]

28. Valdés Rodríguez, O.A.; Palacios Wassenaar, O.M.; Ruíz, R.; Pérez Vázquez, A. Potencial de la asociación Moringa y Ricinus en el subtrópico veracruzano. Rev. Mex. Cienc. Agrícolas 2014, 9, 1673-1686. [CrossRef]

29. Valdés-Rodríguez, O.A.; Sánchez-Sánchez, O.; Pérez-Vázquez, A. Effects of soil texture on germination and survival of non-toxic Jatropha curcas seeds. Biomass Bioenergy 2013, 48, 167-170. [CrossRef]

30. Valdés Rodríguez, O.A. Estudio de Jatropha curcas L. no tóxica: Semillas, Plántulas y Primeros estadíos del Sistema de raíces. Ph.D. Thesis, Universidad Veracruzana, Veracruz, Mexico, 2012.

31. Ribeiro, P.R.; Fernandez, L.G.; De Castro, R.D.; Ligterink, W.; Hilhorst, H.W.M. Physiological and biochemical responses of Ricinus communis seedlings to different temperatures: A metabolomics approach. BMC Plant Biol. 2014, 14, 223. [CrossRef] [PubMed]

32. Fotouo-M, H.; Du Toit, E.S.; Robbertse, P.J. Germination and ultrastructural studies of seeds produced by a fast-growing, drought-resistant tree: Implications for its domestication and seed storage. AoB Plants 2015, 7, 1-12.

33. Díaz-Chuquizuta, P.; Valdés-Rodríguez, O.A.; Tello-Salas, C. Germination responses in physic nut (Jatropha curcas L.) seeds to pregerminative treatments Respuestas de germinación en semillas de piñón (Jatropha curcas L.) a tratamientos pregerminativos. Rev. Chapingo Ser. Hortic. 2017, 23, 89-95. [CrossRef]

34. Van Gelder, H.A.; Poorter, L.; Sterck, F.J. Wood mechanics, allometry, and life-history variation in a tropical rain forest tree community. New Phytol. 2004, 171, 367-378. [CrossRef]

35. Pérez-Vázquez, A.; Hernández-Salinas, G.; Ávila-Reséndiz, C.; Valdés-Rodríguez, O.A.; Gallardo-López, F.; García-Pérez, E.; Ruiz-Rosado, O. Effect of the soil water content on Jatropha seedlings in a tropical climate. Int. Agrophys. 2013, 27, 351-357. [CrossRef]

36. Xu, F.; Guo, W.; Xu, W.; Wei, Y.; Wang, R. Leaf morphology correlates with water and light availability: What consequences for simple and compound leaves. Prog. Nat. Sci. 2009, 19, 1789-1798. [CrossRef]

37. Azcón-Bieto, J.; Talón, M. Fundamentos de Fisiología Vegetal, 2nd ed.; McGraw-Hill Interamericana de España: Barcelona, Spain, 2013; Volume 1, ISBN 9788448192938.

38. Ogburn, R.M.; Edwards, E.J. The ecological water-use strategies of succulent plants. In Advances in Botanical Research; Kader, J.C., Michel, D., Eds.; Academic Press: London, UK, 2010; Volume 55, pp. 179-225. ISBN 9780123808684.

39. Izumi, Y.; Iijima, M. Fractal and Multifractal Analysis of Cassava Root System Grown by the Root-Box Method. Plant Prod. Sci. 2002, 5, 146-151. [CrossRef]

40. González-gonzález, C.E.; Crespo-lópez, G.J. Response of Moringa oleifera Lam to fertilization strategies on lixiviated Ferralitic Red soil. Pastos y Forrajes 2016, 39, 173-177.

41. Reddy, K.R.; Matcha, S.K. Quantifying nitrogen effects on castor bean (Ricinus communis L.) development, growth, and photosynthesis. Ind. Crops Prod. 2010, 31, 185-191. [CrossRef]

42. Valdés-Rodríguez, O.A.; Sánchez-Sánchez, O.; Pérez-Vázquez, A.; Ruiz-Bello, R. Soil texture effects on the development of Jatropha seedlings-Mexican variety “piñón manso". Biomass Bioenergy 2011, 35, 3529-3536. [CrossRef]

43. Schurr, U.; Heckenberger, U.; Herdel, K.; Walter, A.; Feil, R. Leaf development in Ricinus communis during drought stress: Dynamics of growth processes, of cellular structure and of sink-source transition. J. Exp. Bot. 2000, 51, 1515-1529. [CrossRef] [PubMed]

44. Maes, W.H.; Achten, W.M.J.; Reubens, B.; Raes, D.; Samson, R.; Muys, B. Plant-water relationships and growth strategies of Jatropha curcas L. seedlings under different levels of drought stress. J. Arid Environ. 2009, 73, 877-884. [CrossRef]

45. Noda-Leyva, Y.; Pérez-Vázquez, A.; Valdés-Rodríguez, O.A. Establecimiento de tres especies de oleaginosas bajo asociación. Agron. Mesoam. 2015, 26, 323-332. [CrossRef]

46. Krishnamurthy, L.; Zaman-Allah, M.; Marimuthu, S.; Wani, S.P.; Kesava Rao, A.V.R. Root growth in Jatropha and its implications for drought adaptation. Biomass Bioenergy 2012, 39, 247-252. [CrossRef]

(C) 2019 by the authors. Licensee MDPI, Basel, Switzerland. This article is an open access article distributed under the terms and conditions of the Creative Commons Attribution (CC BY) license (http://creativecommons.org/licenses/by/4.0/). 